\title{
BEBERAPA FAKTOR YANG MEMPENGARUHI PERSEPSI WAJIB PAJAK ORANG PRIBADI ATAS PERILAKU PENGGELAPAN PAJAK
}

\author{
Oleh :
}

Angka Wijaya \& Miftahul Jannah

Fakultas Ekonomi Universitas IBA

Jl. Mayor Ruslan Palembang 30113

\begin{abstract}
This study aimed to analyze the factors that influence the perception of the taxpayer on tax evasion behavior. As these factors is the effect of the tax system, the understanding of taxation, service tax authorities and tax penalties. The study population was on the faculty in the accounting department of private universities located in the city of Palembang who had been in accreditation by BAN-PT rated B. The sample was determined by saturation sampling method, the data collected by the distribution of questionnaires. The method of analysis used in this study were multiple linear regression.

Based on the results of the analysis show that the tax system a significant negative effect on the perception of the taxpayer on the behavior of tax evasion, understanding the tax has no effect on the perception of the taxpayer on the ethics of tax evasion, the service tax authorities had no effect on the perception of the taxpayer on the ethics of tax evasion, and tax penalties a significant negative effect on the perception of the taxpayer on tax evasion behavior. The most dominant variable affecting the perception of the taxpayer on the ethics of tax evasion is tax penalties because it has a standard beta coeficient 0.328 .
\end{abstract}

\begin{abstract}
ABSTRAK
Penelitian ini bertujuan untuk menganalisis faktor-faktor yang mempengaruhi persepsi wajib pajak atas perilaku penggelapan pajak. Adapun faktor-faktor tersebut adalah pengaruh sistem perpajakan, pemahaman perpajakan, pelayanan aparat pajak dan sanksi perpajakan. Populasi penelitian ini adalah pada dosen Prodi akuntansi di Perguruan Tinggi Swasta yang berlokasi di kota Palembang yang telah di Akreditasi oleh BAN-PT dengan peringkat B. Sampel dalam penelitian ini ditentukan berdasarkan metode sampling jenuh, data di kumpulkan dengan pembagian kuesioner. Metode analisis penelitian yang digunakan adalah regresi linier berganda.

Berdasarkan hasil analisis menunjukkan bahwa sistem perpajakan berpengaruh negatif dan signifikan terhadap persepsi wajib pajak atas perilaku penggelapan pajak, pemahaman perpajakan tidak berpengaruh terhadap persepsi wajib pajak mengenai etika penggelapan pajak, pelayanan aparat pajak tidak berpengaruh terhadap persepsi wajib pajak mengenai etika penggelapan pajak, dan sanksi perpajakan berpengaruh negatif dan
\end{abstract}


signifikan terhadap persepsi wajib pajak atas perilaku penggelapan pajak. Variabel yang paling dominan mempengaruhi persepsi wajib pajak atas perilaku penggelapan pajak adalah sanksi perpajakan karena memiliki nilai standard coeficient beta 0,328.

\section{Kata kunci: persepsi wajib pajak dan perilaku penggelapan pajak}

\section{PENDAHULUAN}

Pajak menjadi kunci keberhasilan pembangunan di masa akan datang, dalam upaya untuk membiayai pembangunan. Oleh karena itu, pajak merupakan peranan yang sangat penting bagi negara. Menurut Soemitro (2009) pajak merupakan iuran wajib bagi seluruh rakyat yang harus dibayarkan kepada kas negara menurut ketentuan UndangUndang yang berlaku sehingga dapat dipaksakan dan tanpa adanya imbal jasa (kontraprestasi) secara langsung, yang digunakan untuk membiayai pengeluaran umum negara. Oleh karena itu, semua rakyat yang menurut undang-undang termasuk sebagai wajib pajak harus membayar pajak sesuai dengan kewajibannya.

Semua pendapatan negara yang berasal dari pajak akan digunakan untuk membiayai semua pengeluaran umum, yang hal tersebut berarti digunakan untuk menyejahterakan rakyat. Akan tetapi, tidak banyak rakyat yang dapat merasakan apa yang telah mereka keluarkan. Kemanakah uang rakyat yang telah disetorkan selama ini. Pertanyaan tersebut sering kali muncul dibenak masyarakat. Selain itu, dikatakan penerimaan pajak meningkat setiap tahunnya, tetapi bentuk dari pengeluaran negara tersebut terus menerus berlanjut, dikhawatirkan akan mengakibatkan keengganan rakyat untuk membayar pajak bahkan akan cenderung menggelapkan pajak.

Hal utama yang melatarbelakangi adanya tindakan penggelapan pajak adalah kebutuhan dasar manusia dalam upaya memenuhi kebutuhan pokok hidupnya. Wajib pajak merasa telah bersusah payah untuk memperoleh pendapatan tetapi dengan begitu saja dipungut oleh pajak negara (Rahayu, 2010). Selain itu, yang membuat wajib pajak berusaha menyelundupkan pajak antara lain sistem perpajakan di Indonesia yang belum optimal, pemahaman wajib pajak yang masih rendah, pelayanan aparat pajak yang mengecewakan, sanksi pada sistem perpajakan di Indonesia dinilai kurang efektif dan kurang menimbulkan efek jera. 
Korupsi dalam dunia perpajakan dikenal dengan istilah penggelapan pajak (tax evasion). Penggelapan pajak cenderung dilakukan oleh wajib pajak nakal yang enggan membayar pajak untuk mengurangi atau sama sekali menghapus hutang pajak yang berdasarkan ketentuan yang berlaku dengan jalan bekerjasama dengan pihak fiskus atau petugas pajak.

Terungkapnya beberapa kasus mafia pajak, secara tidak langsung tentunya berpengaruh terhadap perubahan perilaku wajib pajak dalam membayarkan pajaknya. Namun penggelapan pajak ini tidak semata-mata kesalahan wajib pajak saja tetapi diperlancar dengan adanya kerjasama oleh petugas pajak di Kantor Pelayanan Pajak.

Terdapat beberapa penelitian yang berkaitan dengan perilaku penggelapan pajak. Prasetyo (2010), Persepsi Etis Penggelapan Pajak Bagi Wajib Pajak di Wilayah Surakarta. Ruang lingkup penelitian ini dilakukan pada wajib pajak di wilayah Surakarta dengan sampel sebanyak 75 wajib pajak. Berdasarkan hasil penelitian ditarik kesimpulan bahwa $85,74 \%$ pegawai swasta tidak setuju dengan adanya berbagai bentuk praktik penggelapan pajak, $82,13 \%$ wiraswasta tidak setuju dengan adanya berbagai bentuk praktik penggelapan pajak, dan $95,56 \%$ pegawai negeri sipil tidak setuju dengan adanya praktik penggelapan pajak.

Rachmadi (2014),“ Faktor- Faktor yang Mempengaruhi Persepsi Wajib Pajak Orang Pribadi Atas Perilaku Penggelapan Pajak”. Ruang lingkup penelitian ini dilakukan pada wajib pajak yang berada di wilayah Semarang dengan responden berjumlah 100 responden. Hasil penelitian menunjukkan adanya faktor-faktor yang mempengaruhi persepsi wajib pajak orang pribadi atas perilaku penggelapan pajak ialah pemahaman perpajakan, pelayanan aparat pajak, sanksi perpajakan berpengaruh secara signifikan terhadap persepsi wajib pajak orang pribadi atas perilaku penggelapan pajak.

Suminarsasi (2011), "Pengaruh Keadilan, Sistem Perpajakan, dan Diskriminasi Terhadap Persepsi Wajib Pajak Mengenai Etika Penggelapan Pajak (Tax Evasion)". Hasil penelitian menunjukan bahwa keadilan dan sistem perpajakan berpengaruh signifikan terhadap persepsi wajib pajak mengenai etika penggelapan pajak, sedangkan diskriminasi tidak berpengaruh terhadap persepsi wajib pajak mengenai etika penggelapan pajak. 
Penelitian ini mengkaji tentang faktor-faktor yang mempengaruhi persepsi Wajib Pajak Orang Pribadi (WPOP) atas perilaku penggelapan pajak. Penelitian ini merupakan pengembangan dari penelitian yang pernah dilakukan oleh, Prasetyo (2010), Rachmadi (2014) dan Suminarsasi (2011). Penelitian ini menggunakan variabel-variabel independen antara lain, sistem perpajakan, pemahaman perpajakan, pelayanan fiskus dan sanksi perpajakan.

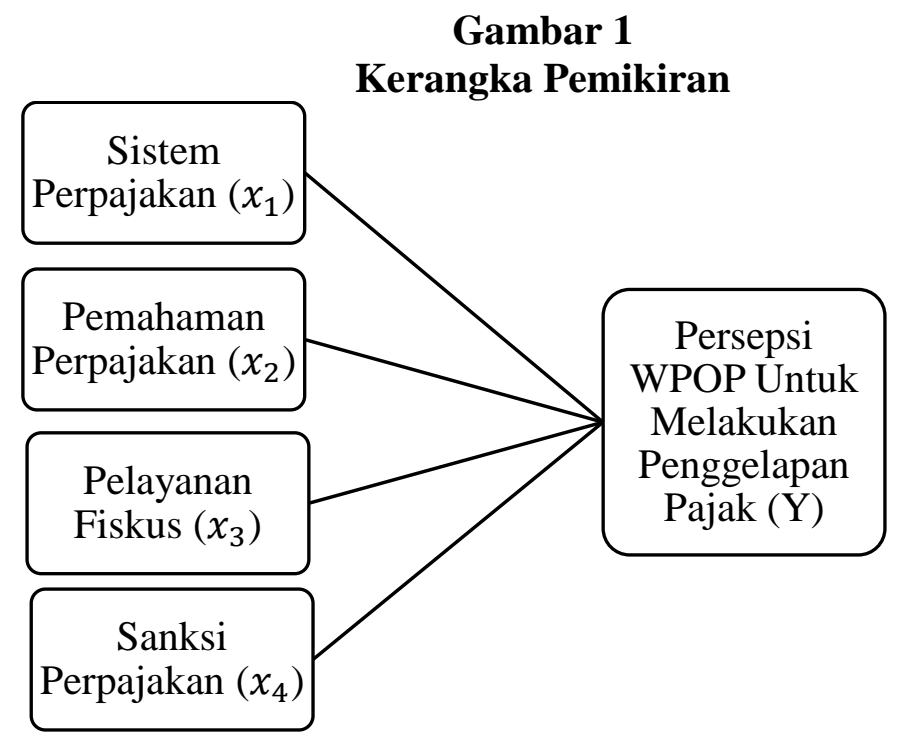

Penelitian ini menggunakan sampel Wajib Pajak Orang Pribadi yang berdomisili di Palembang dan bekerja sebagai Dosen Perguruan Tinggi Swasta (PTS) Program Studi (Prodi) Akuntansi di Palembang.

\section{RUMUSAN MASALAH}

Berdasarkan latar belakang yang telah diuraikan diatas, identifikasi masalah dalam penelitian ini adalah :

1. Apakah persepsi Wajib Pajak Orang Pribadi mengenai sistem perpajakan berpengaruh atas perilaku penggelapan pajak ?

2. Apakah persepsi Wajib Pajak Orang Pribadi mengenai pemahaman perpajakan berpengaruh atas perilaku penggelapan pajak?

3. Apakah persepsi Wajib Pajak Orang Pribadi mengenai pelayanan fiskus berpengaruh atas perilaku penggelapan pajak?

4. Apakah persepsi Wajib Pajak Orang Pribadi mengenai sanksi perpajakan berpengaruh atas perilaku penggelapan pajak? 


\section{PEMBAHASAN}

\section{Populasi}

Populasi adalah wilayah generalisasi yang terdiri atas : obyek/subyek yang mempunyai kualitas dan karakteristik tertentu yang ditetapkan oleh peneliti untuk dipelajari dan kemudian ditarik kesimpulannya (Sugiyono, 2009). Pada penelitian ini peneliti mengambil objek penelitian pada dosen prodi akuntansi di Perguruan Tinggi Swasta di kota Palembang yang telah di Akreditasi oleh BAN-PT dengan peringkat B.

Tabel 1

Daftar Perguruan Tinggi Swasta Akreditasi B Di Kota Palembang

\begin{tabular}{|c|l|l|}
\hline No & \multicolumn{1}{|c|}{$\begin{array}{c}\text { Nama Perguruan Tinggi } \\
\text { Swasta }\end{array}$} & \multicolumn{1}{c|}{ Alamat } \\
\hline 1 & Universitas Bina Darma & $\begin{array}{l}\text { Jl. Jenderal Ahmad Yani No.3 Plaju Palembang } \\
30264\end{array}$ \\
\hline 2 & Universitas IBA & Jl. Mayor Ruslan Palembang 30113 \\
\hline 3 & Universitas Muhammadiyah & $\begin{array}{l}\text { Jl. Jenderal Ahmad Yani 13 Ulu Palembang } \\
30263\end{array}$ \\
\hline 4 & Universitas Tridinanti & Jl. Kapten Marzuki No.2446 Palembang 30129 \\
\hline 5 & Universitas PGRI & Jl. Jenderal Ahmad Yani Palembang 30263 \\
\hline 6 & Universitas Syakyakirti & Jl. Sultan Moh Mansyur Palembang 30145 \\
\hline
\end{tabular}

Sumber : PDDIKTI (2016)

\section{Sampel}

Sampel adalah sebagian dari jumlah dan karateristik yang dimiliki oleh populasi tersebut (Sugiyono,2009).

Teknik pengambilan sampel yang digunakan dalam penelitian ini adalah sampling jenuh (sensus). Menurut (Sugiyono,2009), sampling jenuh adalah teknik penentuan sampel bila semua anggota populasi digunakan sebagai sampel. Penulis 
menggunakan sampling jenuh dikarenakan terbatasnya jumlah populasi, sehingga semua anggota populasi dijadikan sampel penelitian.

Di kota Palembang terdapat 6 Perguruan Tinggi Swasta yang telah terakreditasi B oleh BAN-PT, tetapi peneliti hanya mengambil 3 Universitas sebagai sampel karena kemudahan dalam memperoleh data, diantaranya :

Tabel 2

Daftar Jumlah Dosen

\begin{tabular}{|c|l|c|}
\hline No & \multicolumn{1}{|c|}{ Nama Perguruan Tinggi Swasta } & Jumlah Dosen Prodi Akuntansi \\
\hline 1 & Universitas Bina Darma & 16 \\
\hline 2 & Universitas IBA & 8 \\
\hline 3 & Universitas Muhammadiyah & 33 \\
\hline \multicolumn{2}{|c|}{ Total } & $\mathbf{5 7}$ \\
\hline
\end{tabular}

Sumber : Olahan 2016

Berdasarkan keterangan tabel di atas, ada tiga Universitas yang tidak dijadikan sampel dalam penelitian ini, yaitu Universitas Tridinanti, Universitas Syakyakirti, dan Universitas PGRI peneliti tidak mendapatkan informasi jumlah dosen prodi akuntansi pada Universitas tersebut dikarenakan peneliti tidak mendapatkan izin untuk meneliti.

Responden dalam penelitian ini adalah dosen Prodi akuntansi di Perguruan Tinggi Swasta di Palembang. Dalam penelitian ini, disebarkan 57 kuesioner kepada dosen Prodi akuntansi (sampel). Adapun data distribusi sampel penelitian dapat dilihat dalam tabel berikut ini :

Tabel 3

Data Distribusi Sampel Penelitian

\begin{tabular}{|c|c|c|c|}
\hline No & Keterangan & Jumlah & Persentase \\
\hline 1 & Kuesioner yang dibagikan & 57 & $100 \%$ \\
\hline 2 & Kuesioner yang kembali & 47 & $82,46 \%$ \\
\hline 3 & Kuesioner yang tidak kembali & 10 & $17,54 \%$ \\
\hline
\end{tabular}

Sumber : Olahan (2016) 
Dari tabel 3 diatas dapat dilihat bahwa kuesioner yang dibagikan berjumlah 57 buah, namun kuesioner yang kembali sebanyak 47 atau sebesar $82,46 \%$, sedangkan kuesioner yang tidak kembali sebanyak 10 atau sebesar 17,54\%, maka dalam penelitian ini data yang dapat diolah sebanyak 47 kuesioner atau sebesar 82,46\%.

Karakteristik responden menggambarkan keadaan dan kondisi dari responden. Berikut ini akan dikemukakan gambaran umum responden yang menjadi obyek dalam penelitian ini, yaitu dosen Prodi akuntansi di Perguruan Tinggi Swasta di kota Palembang. Karakteristik responden dapat dilihat di tabel dibawah ini:

Tabel 4

Karakteristik Responden

\begin{tabular}{|c|c|c|c|}
\hline \multicolumn{2}{|c|}{ Karakteristik } & Jumlah & Persentase \\
\hline \multirow[t]{3}{*}{ Jenis Kelamin } & Laki-laki & 25 & $53,20 \%$ \\
\hline & Perempuan & 22 & $46,80 \%$ \\
\hline & Total & 47 & $100 \%$ \\
\hline \multirow[t]{4}{*}{ Usia } & $25-35$ tahun & 8 & $17,02 \%$ \\
\hline & $36-45$ tahun & 22 & $46,80 \%$ \\
\hline & $>46$ tahun & 17 & $36,18 \%$ \\
\hline & Total & 47 & $100 \%$ \\
\hline \multirow[t]{4}{*}{ Lama Bekerja } & 5-10 tahun & 8 & $17,02 \%$ \\
\hline & 11-20 tahun & 25 & $53,20 \%$ \\
\hline & $>21$ tahun & 14 & $29,78 \%$ \\
\hline & Total & 47 & $100 \%$ \\
\hline \multirow[t]{4}{*}{ Pendidikan Terakhir } & S1 & 7 & $14,90 \%$ \\
\hline & S2 & 29 & $61,70 \%$ \\
\hline & S3 & 11 & $23,40 \%$ \\
\hline & Total & 47 & $100 \%$ \\
\hline
\end{tabular}

Sumber :Olahan (2016) 


\section{Data yang Digunakan}

Data yang digunakan dalam penelitian ini adalah menggunakan data primer dan data sekunder. Data primer adalah sumber data yang diperoleh secara langsung dari narasumbernya. Data sekunder adalah data yang diperoleh atau dikumpulkan peneliti dari berbagai sumber yang telah ada.

\section{Teknik Pengumpulan Data}

Teknik Pengumpulan data yang digunakan dalam penelitian adalah field research (penelitian lapangan), data diproleh dengan menyebarkan kuisioner. Penyebaran kuisioner yang telah disusun, di sejumlah pernyataan tertulis disampaikan pada responden untuk ditanggapi sesuai dengan kondisi yang dialami oleh responden.yang bersangkutan. Responden akan menerima kuisioner yang berisi pernyataan mengenai penggelapan pajak, sistem perpajakan, pemahaman perpajakan, pelayanan fiskus, dan sanksi perpajakan. Kuisioner juga dilengkapi dengan keterangan identitas responden dan petunjuk pengisian yang sederhana dan jelas untuk membantu responden melakukan pengisian dengan lengkap.

Penyusunan kuisioner ini menggunakan skala likert, skala ini terdiri dari sejumlah pernyatan yang meminta reaksi responden, reaksi ini diungkapkan dari tingkat sangat setuju sampai sangat tidak setuju. Untuk mengukur pendapat responden digunakan skla lima angka yautu angka 5 untuk pendapat sangat setuju (SS) dan angka 1 untuk sangat tidak setuju (STS). Perinciannya adalah sebagai berikut :

Angka 1 = Sangat Tidak Setuju (STS)

Angka 2 = Tidak Setuju (TS)

Angka $3=\operatorname{Netral}(\mathrm{N})$

Angka 4 = Setuju (S)

Angka 5 = Sangat Setuju (SS)

\section{Operasional Variabel}

Dalam penelitian terdapat empat variabel. Empat variabel independen $(\mathrm{X})$ dan satu variabel dependen (Y). Variabel dalam penelitian diuraikan sebagai berikut :;

1. Sistem Perpajakan sebagai variabel X1 (Variabel independen) 
2. Pemahaman Perpajakan sebagai variabel X2 (Variabel independen)

3. Pelayanan Fiskus sebagai variabel X3 (Variabel independen)

4. Sanksi Perpajakan sebagai variabel X4 (Variabel independen)

5. Penggelapan Pajak sebagai Y (Variabel dependen)

Operasional Variabel penelitian ini dapat dijabarkan secara lengkap pada tabel berikut ini :

Tabel 5

Operasional Variabel

\begin{tabular}{|c|c|c|c|c|}
\hline No & Variabel & Dimensi & Indikator & Skala \\
\hline 1 & $\begin{array}{l}\text { Sistem } \\
\text { perpajakan } \\
(\mathrm{X} 1)\end{array}$ & $\begin{array}{l}\text { - Sarana pelaporan pajak } \\
\text { - Sarana penyampaian SPT } \\
\text { - Sarana peraturan pajak } \\
\text { - Sarana pendaftaran pajak } \\
\text { - Sarana prosedur pajak } \\
\end{array}$ & 5 pernyataan & Likert \\
\hline 2 & $\begin{array}{l}\text { Pemahaman } \\
\text { Perpajakan } \\
\text { (X2) }\end{array}$ & $\begin{array}{l}\text { - Tingkat pengetahuan hak dan } \\
\text { kewajiban sebagai wajib pajak } \\
\text { - Tingkat pengetahuan mengenai } \\
\text { tarif perpajakan } \\
\text { - Tingkat pengetahuan mengenai } \\
\text { sanksi perpajakan } \\
\text { - Tingkat pemahaman mengenai } \\
\text { peraturan perpajakan }\end{array}$ & 5 pernyataan & Likert \\
\hline 3 & $\begin{array}{l}\text { Pelayanan } \\
\text { Fiskus (X3) }\end{array}$ & $\begin{array}{l}\text { - Tingkat pelayanan fiskus } \\
\text { - penyuluhan yang dilakukan oleh } \\
\text { Fiskus } \\
\text { - Motivasi aparat sebagai } \\
\text { pelayanan publik }\end{array}$ & 4 pernyataan & Likert \\
\hline 4 & $\begin{array}{l}\text { Sanksi } \\
\text { Perpajakan } \\
(\mathrm{X} 4)\end{array}$ & $\begin{array}{l}\text { - Tingkat sanksi pidana yang } \\
\text { dikenakan bagi pelanggar aturan } \\
\text { perpajakan } \\
\text { - Tingkat sanksi administrasi } \\
\text { - Pemberian sanksi tanpa toleransi. } \\
\text { - Sanksi sebagai sarana mendidik } \\
\text { wajib pajak }\end{array}$ & 4 pernyataan & Likert \\
\hline
\end{tabular}

\section{Hasil Uji Validitas}

Uji validitas digunakan untuk menentukan sebesar valid suatu item pernyataan mengukur variabel yang diteliti. Uji validitas ini dilakukan dengan mengkorelasikan antara skor masing-masing butir pernyataan dengan skor total yang diperoleh dari penjumlahan semua skor pernyataan. Syarat untuk memenuhi validitas yaitu jika $r_{\text {hitung }}$ 
lebih besar dari $r_{\text {tabel }}$ yakni 0,3, maka butir pernyataan tersebut dinyatakan valid dan begitu sebaliknya (Sugiyono,2012).

Tabel 6

Hasil Pengujian Validitas

$(\mathrm{n}=47, \mathrm{a}=5 \%, \mathrm{r}$ tabel $=0,3)$

\begin{tabular}{|c|c|c|c|c|}
\hline Variabel & Butir Pernyataan & $r_{\text {hitung }}$ & $r_{\text {tabel }}$ & Keterangan \\
\hline \multirow{5}{*}{ Sistem Perpajakan (X1) } & 1 & 0,881 & 0,3 & Valid \\
\hline & 2 & 0,846 & 0,3 & Valid \\
\hline & 3 & 0.692 & 0,3 & Valid \\
\hline & 4 & 0,444 & 0,3 & Valid \\
\hline & 5 & 0,790 & 0,3 & Valid \\
\hline \multirow{5}{*}{ Pemahaman Perpajakan (X2) } & 6 & 0,681 & 0,3 & Valid \\
\hline & 7 & 0,703 & 0,3 & Valid \\
\hline & 8 & 0,683 & 0,3 & Valid \\
\hline & 9 & 0,826 & 0,3 & Valid \\
\hline & 10 & 0,826 & 0,3 & Valid \\
\hline \multirow{4}{*}{ Pelayanan Fiskus (X3) } & 11 & 0,916 & 0,3 & Valid \\
\hline & 12 & 0,879 & 0,3 & Valid \\
\hline & 13 & 0,896 & 0,3 & Valid \\
\hline & 14 & 0,885 & 0,3 & Valid \\
\hline \multirow{4}{*}{ Sanksi Perpajakan (X4) } & 15 & 0,853 & 0,3 & Valid \\
\hline & 16 & 0,857 & 0,3 & Valid \\
\hline & 17 & 0,911 & 0,3 & Valid \\
\hline & 18 & 0,892 & 0,3 & Valid \\
\hline \multirow{5}{*}{$\begin{array}{l}\text { Persepsi WPOP atas Perilaku } \\
\text { Penggelapan Pajak (Y) }\end{array}$} & 19 & 0,360 & 0,3 & Valid \\
\hline & 20 & 0,496 & 0,3 & Valid \\
\hline & 21 & 0,792 & 0,3 & Valid \\
\hline & 22 & 0,812 & 0,3 & Valid \\
\hline & 23 & 0,632 & 0,3 & Valid \\
\hline
\end{tabular}


Variabel sistem perpajakan, pemahaman perpajakan, pelayanan fiskus, dan sanksi perpajakan terdiri atas 23 pernyataan. Dari 23 pernyataan pada tabel 4.3 adalah valid. Ini terlihat dari besarnya koefisien validitas yang dihasilkan oleh setiap item pernyataan yang semuanya diatas 0,3 . Jadi seluruh pernyataan yang digunakan dalam mengukur faktor-faktor persepsi wajib pajak orang pribadi atas perilaku penggelapan pajak telah memiliki ketepatan yang baik.

\section{Hasil Uji Realibilitas}

Pengujian reliabilitas digunakan untuk menyatakan kehandalan jawaban seseorang terhadap pernyataan yang ada dalam kuesioner apakah konsisten atau stabil dari waktu ke waktu. Penelitian ini akan melakukan realibilitas dengan uji statistik dengan Croncbach Alpha dimana jilka nilai Croncbach Alpha lebih besar atau sama dengan 0,6 berarti dinyatakan reliable (Sugiyono, 2012).

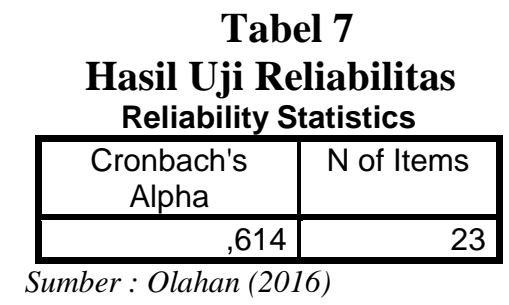

Berdasarkan hasil uji reliabilitas pada tabel 7 dapat dilihat bahwa nilai koefisien Cronbach's Alpha lebih besar dari 0,6 yaitu 0,614. Nilai koefisien reliabilitas ini menunjukkan hasil pengukuran yang dihasilkan oleh instrumen yang digunakan menunjukkan konsistensi yang cukup baik pada setiap respondenyang berarti bila pernyataan itu diajukan kembali akan diperoleh jawaban yang relatif sama dengan jawaban sebelumnya.

\section{Hasil Uji Asumsi Klasik}

Pengujian asumsi klasik bertujuan untuk mengetahui, menguji serta memastikan kelayakan model regresi yang digunakan dalam penelitian ini, dimana variabel tersebut terdistrubusi secara normal, bebas dari multikolinearitas dan heteroskedastisitas. 


\section{Hasil Uji Normalitas}

Data-data bertipe skala sebagai pada umumnya mengikuti asumsi distribusi normal. Namun, tidak mustahil suatu data tidak mengikuti asumsi normalitas. Untuk mengetahui kepastian sebaran data yang diperoleh harus dilakukan uji normalitas terhadap data yang bersangkutan. Dengan demikian, analisis statistika yang pertama harus digunakan dalam rangka analisis data adalah analisis statistik berupa uji normalitas. Uji normalitas bertujuan untuk menguji variabel independen, dan variabel dependen. Variabel independenyaitu sistem perpajakan, pemahaman perpajakan, pelayanan fiskus, dan sanksi perpajakan dan variabel dependenadalah penggelapan pajak keduanya memiliki distribusi normal atau tidak, berikut ini gambar grafik uji normalitas data pada grafik $p p-p l o t$.

\section{Gambar 2}

Hasil Pengujian Normalitas dengan Plot Garis Diagonal

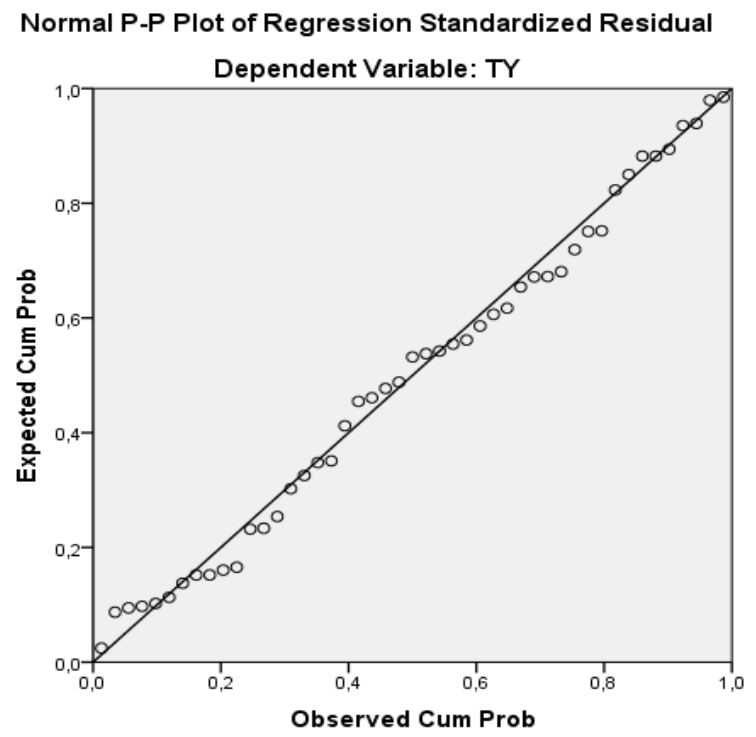

Sumber : Olahan (2016)

Pada grafik normal plot terlihat titik-titik menyebar di sekitar garis diagonal, serta penyebarannya mengikuti arah garis diagonal. Kedua grafik ini menunjukkan bahwa model regresi layak dipakai karena asumsi normalitas(Ghozali 2011 :163).

Sedangkan dalam uji Kolmogorov Smirnovjika nilai signifikasi lebih besar dari 0,05 maka data tidak menyimpang dan kurvanya normal terlihat pada tabel berikut : 
Tabel 8.

Hasil Uji Kolmogorov Smirnov

One-Sample Kolmogorov-Smirnov Test

\begin{tabular}{|c|c|c|}
\hline & $\begin{array}{c}\text { Unstandardized } \\
\text { Residual }\end{array}$ \\
\hline $\mathrm{N}$ & & 47 \\
\hline Normal Parameters ${ }^{a, b}$ & Mean & $0 \mathrm{E}-7$ \\
\hline & $\begin{array}{l}\text { Std. Deviation } \\
\text { Absolute }\end{array}$ & $\begin{array}{r}1,74145426 \\
080\end{array}$ \\
\hline Most Extreme Differences & Positive & ,080 \\
\hline & Negative &,- 056 \\
\hline Kolmogorov-Smirnov Z & & ,545 \\
\hline Asymp. Sig. (2-tailed) & & 928 \\
\hline
\end{tabular}

a. Test distribution is Normal.

b. Calculated from data.

Sumber : Olahan (2016)

Dari hasil pengujian statistik One-Sample Kolmogorov Smirnov pada tabel diatas juga menunjukkan besarnya nilai Kolmogorov- Smirnov zadalah 0,545 dan signifikan 0,928 yang berarti data nilai residual terdistribusi normal karena nilai signifikan lebih besar dari $5 \%$ atau $0,05(0,928>0,05)$.

\section{Hasil Uji Multikolinieritas}

Pengujian multikolinieritas dilakukan untuk menguji apakah pada model regresi ditemukan adanya korelasi antar variabel independen. Untuk mendeteksi adanya problem multikolinieritas, maka dapat dilakukan dengan melihat nilai Tolerance dan Variance Inflation Factor (VIF) serta besaran korelasi antar variabel independen.

\section{Tabel 9}

Hasil Uji Multikolinieritas

Coefficients $^{a}$

\begin{tabular}{|ll|r|r|}
\hline \multirow{2}{*}{ Model } & \multicolumn{2}{|c|}{ Collinearity Statistics } \\
\cline { 3 - 4 } & & \multicolumn{1}{|c|}{ Tolerance } & \multicolumn{1}{c|}{ VIF } \\
\hline \multirow{2}{*}{\begin{tabular}{l} 
(Constant) \\
\multirow{2}{*}{1}
\end{tabular}} & & \\
& TX1 &, 896 & 1,117 \\
& TX2 &, 883 & 1,133 \\
& TX3 &, 968 & 1,033 \\
& TX4 &, 822 & 1,217 \\
\hline
\end{tabular}

a. Dependent Variable: TY

Sumber: Olahan (2016) 
Hasil perhitungan nilai tolerance menunjukkan tidak ada nilai variabel independen yang memiliki nilai tolerance kurang dari 0,1 yang berarti tidak ada korelasi antara variabel independen. Hasil perhitungan nilai Variance Inflation Factor (VIF) juga menunjukkan hal yang sama. Dengan nilai VIF untuk masing-masing variabel independen Sistem Perpajakan (X1) 1,117, Pemahaman Perpajakan (X2) 1,133, Pelayanan fiskus (X3) 1,033, Sanksi Perpajakan (X4) 1,217. Jadi dapat disimpulkan bahwa persamaan regresi tidak terdapat problem multikolinieritas karena nilai tolerance $<0,10$ dan nilai VIF (variance inflation factor) $<10$.

\section{Hasil Uji Heteroskedastisitas}

Uji heteroskedastisitas bertujuan untuk menguji apakah dalam model regresi terjadi ketidaksamaan variance dari residual satu pengamatan yang lain. Heteroskedastisitas kesalahan yang terjadi tidak secara acak tetapi menunjukkan hubungan yang sistematis sesuai dengan besarnya satu atau lebih variabel. Berdasarkan hasil pengolahan data, maka hasil Scatterplot dapat dilihat pada gambar berikut :

\section{Gambar 3.}

\section{Hasil Uji Heteroskedastisitas}

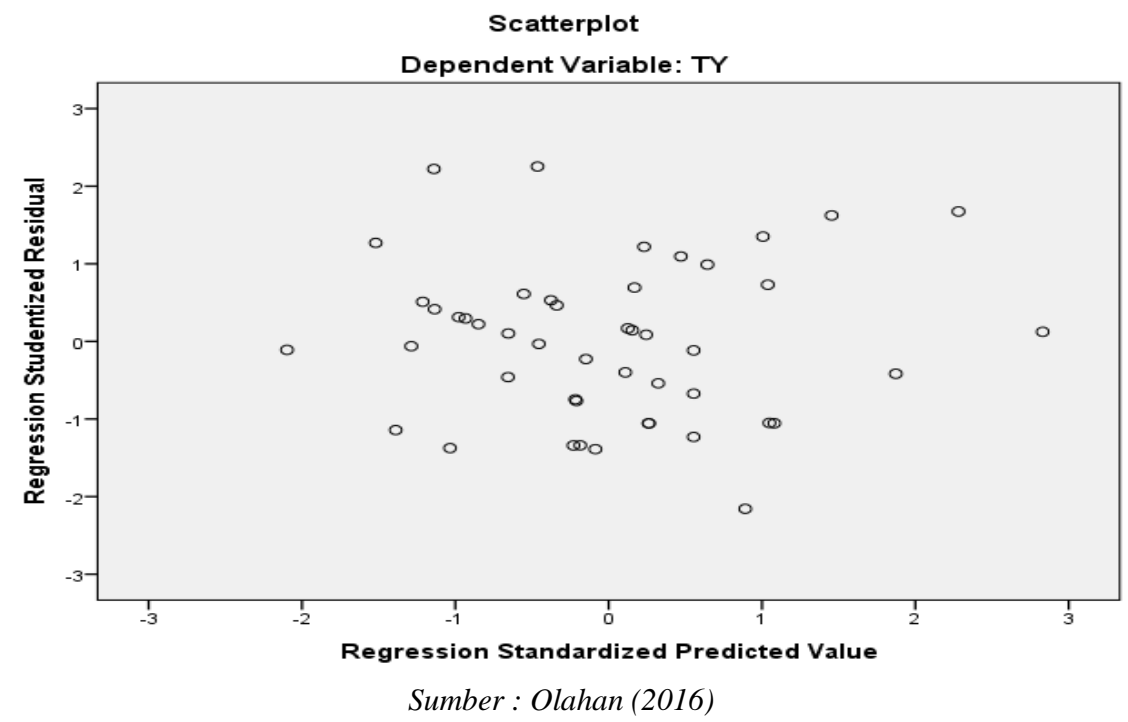


Dari grafik Scatterplot yang ada pada gambar 3 dapat dilihat bahwa titik menyebar secara acak, serta tersebar baik diatas maupun dibawah angka nol pada sumbu Y. Hal ini dapat disimpulkan bahwa tidak terjadi heteroskedastisitas pada model regresi (Ghozali,2011).

\section{Analisa Data dan Pengujian Hipotesis}

Setelah melakukan pengujian asumsi klasik dan telah terbukti bahwa data terbebas dari asumsi-asumsi klasik, maka data dalam penelitian ini telah memenuhi syarat untuk melakukan pengujian analisis regresi berganda.

Uji regresi linear berganda yaitu untuk memenuhi gambaran mengenai pengaruh antara dua atau lebih variabel $\mathrm{X}$ sebagai variabel independen (bebas) dengan variabel $\mathrm{Y}$ sebagai variabel dependen (terkait).

Dalam penelitian ini, analisis regresi liner berganda dilakukan agar mengetahui koefisien regresi atau besarnya pengaruh variabel independennya yaitu Sistem Perpajakan (X1), Pemahaman Perpajakan (X2), Pelayanan Aparat Pajak (X3), Sanksi Perpajakan (X4). Penelitian ini menggunakan analisis regresi linear berganda karena memiliki independen lebih dari satu.

Tabel 10

Hasil Analisis Regresi Linear Berganda Coefficients $^{\mathrm{a}}$

\begin{tabular}{|rr|r|r|r|}
\hline Model & \multicolumn{2}{|c|}{ Unstandardized Coefficients } & \multicolumn{1}{c|}{$\begin{array}{c}\text { Standardized } \\
\text { Coefficients }\end{array}$} \\
\cline { 3 - 5 } & & \multicolumn{1}{|c|}{ B } & Std. Error & \multicolumn{2}{|c|}{ Beta } \\
\hline \multirow{2}{*}{ (Constant) } & 22,345 & 3,801 &,- 279 \\
1 & TX1 &,- 256 &, 125 &,- 038 \\
& TX2 &,- 035 &, 128 &,- 192 \\
& TX3 &,- 167 &, 114 &,- 328 \\
\hline
\end{tabular}

a. Dependent Variable: TY

Sumber : Olahan (2016) berikut :

Dari hasil pengolahan data ini maka, Persamaan regresi yang digunakan sebagai

$$
\begin{gathered}
\mathrm{Y}=\mathrm{a}+\mathrm{b}_{1} x_{1}+b_{2} x_{2}+b_{3} x_{3}+b_{4} x_{4}+\mathrm{e} \\
\mathrm{Y}=22,345-0,256 \mathrm{X}_{1}-0,035 \mathrm{X}_{2}-0,167 \mathrm{X}_{3}-0,290 \mathrm{X}_{4}+\mathrm{e}
\end{gathered}
$$

Keterangan : 


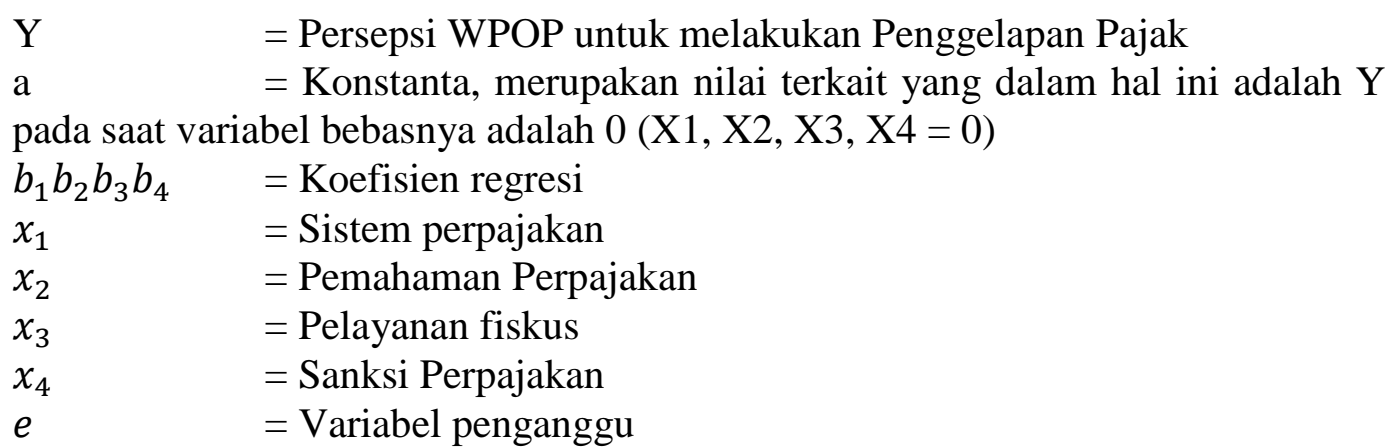

Dari hasil pengujian regresi diatas, maka dapat diketahui bahwa:

1. Koefisien regresi pada variabel sistem perpajakan berarah negatif dan signifikan sebesar -0,256 hal ini berarti jika variabel sistem perpajakan bertambah satu satuan maka variabel penggelapan pajak berkurang sebesar 0,256 satuan atau sebesar 25,6\%.

2. Koefisien regresi pada variabel pemahaman perpajakan berarah negatif dan signifikan $-0,035$, hal ini berarti jika variabel pemahaman perpajakan bertambah satu satuan maka variabel penggelapan pajak berkurang sebesar 0,035 satuan atau sebesar 3,5\%.

3. Koefisien regresi pada variabel pelayanan fiskus berarah negatif dan signifikan sebesar -0,167, hal ini berarti jika variabel pelayanan fiskus bertambah satu satuan maka variabel penggelapan pajak berkurang sebesar 0,167 satuan atau sebesar 16,7\%.

4. Koefisien regresi pada variabel sanksi perpajakan berarah negatif dan signifikan sebesar $-0,290$, hal ini berarti jika variabel sanksi perpajakan bertambah satu satuan maka variabel penggelapan pajak berkurangsebesar 0,290 satuan atau $29 \%$.

Berdasarkan hasil uji persamaan regresi berganda maka dapat dilihat variabel independen yang paling dominan mempengaruhi penggelapan pajak adalah variabel persepsi wajib pajak orang pribadi atas sanksi perpajakan, karena dilihat berdasarkan nilai beta terbesar sebesar $-0,328$.

\section{Hasil Uji Hipotesis}

\section{Hasil Uji t (Parsial)}

Uji t bertujuan untuk melihat apakah terdapat pengaruh secara individu variabel independen terhadap variabel dependen. dalam penelitian ini terdapat empat variabel independen yaitu sistem perpajakan, pemahaman perpajakan, pelayanan fiskus, dan sanksi perpajakan oleh sebab itu perlu adanya pengujian untuk masing-masing variabel agar dapat dilihat apakah dari masing-masing variabel sama-sama memiliki pengaruh atau bahkan sebaliknya. Untuk melakukan menguji variabel secara parsial maka 
dibutuhkan pengujian $\mathrm{t}$ agar dapat diketahui secara parsial mengenai pengaruh dari masing-masing variabel. Pengujian dapat dilihat pada tingkat signifikasi 0,05. Hasil uji statistik $\mathrm{t}$ dapat dilihat pada tabel, jika nilai probability $\mathrm{t}<0,05$ maka Ho ditolak, sedangkan jika nilai probability $\mathrm{t}>0,05$ maka Ho diterima(Ghozali, 2011).

Untuk memberikan gambaran mengenai hipotesis yang akan diuji berikut ini adalah hipotesisnya :

Ho1 : Tidak terdapat pengaruh sistem perpajakan terhadap persepsi Wajib Pajak Orang Pribadi (WPOP) atas perilaku penggelapan pajak.

Ha1 : Terdapat pengaruh sistem perpajakan terhadap persepsi Wajib Pajak Orang Pribadi(WPOP) atas perilaku penggelapan pajak.

Ho2 : Tidak terdapat pengaruh pemahaman perpajakan terhadap persepsi Wajib Pajak Orang Pribadi (WPOP) atas perilaku penggelapan pajak.

Ha2 : Terdapat pengaruh pemahaman perpajakan terhadap persepsi Wajib Pajak Orang Pribadi(WPOP) atas perilaku penggelapan pajak.

Ho3 : Tidak terdapat pengaruh pelayanan aparat pajak terhadap persepsi Wajib Pajak Orang Pribadi(WPOP) atas perilaku penggelapan pajak

Ha3 : Terdapat pengaruh pelayanan aparat pajak terhadap persepsi Wajib Pajak Orang Pribadi (WPOP) atas perilaku penggelapan pajak

Ho4 : Tidak terdapat pengaruh sanksi perpajakan terhadap persepsi Wajib Pajak Orang Pribadi(WPOP) atas perilaku penggelapan pajak

Ha4 : Terdapat pengaruh sanksi perpajakan terhadap persepsi Wajib Pajak Orang Pribadi (WPOP) atas perilaku penggelapan pajak

Tabel 11

Uji Hipotesis dengan Uji T Coefficients $^{a}$

\begin{tabular}{|ll|r|r|}
\hline Model & & \multicolumn{1}{c|}{ T } & \multicolumn{1}{l|}{ Sig. } \\
& & &, 000 \\
\hline & (Constant) & 5,879 &, 047 \\
\multirow{2}{*}{1} & TX1 & $-2,049$ &, 785 \\
& TX2 &,- 274 &, 151 \\
& TX3 & $-1,463$ &, 026 \\
\hline
\end{tabular}

a. Dependent Variable: TY

Sumber : Olahan (2016)

Berdasarkan dari hasil pengujian dari tabel 11 dapat disimpulkan sebagai berikut :

a. Hasil Uji Hipotesis 1 : Pengaruh sistem perpajakan terhadap persepsi Wajib Pajak Orang Pribadi (WPOP) atas perilaku penggelapan pajak.

Berdasarkan hasil pengujian hipotesis yang ditunjukkan pada tabel 4.8, variabel sistem perpajakan mempunyai tingkat signifikasi sebesar 0,047 dan nilai t sebesar - 
2,049. Hal ini berarti Ho1 ditolak sehingga dapat dikatakan bahwa sistem perpajakan berpengaruh negatif dan signifikan terhadap penggelapan pajak karena tingkat signifikasi yang dimiliki variabel sistem perpajakan $<0,05(0,047<0,05)$ dan nilai thitung > 2,01 (-2,049>2,01). Hasil penelitian ini konsisten dengan penelitian yang dilakukan Suminarsasi (2011) menyatakan bahwa sistem perpajakan memiliki korelasi negatif signifikan terhadap penggelapan pajak. Semakin baik, mudah dan terkendali prosedur sistem perpajakan yang diterapkan, maka tindak penggelapan pajak dianggap suatu tindakan yang tidak etis bahkan mampu meminimalisir perilaku tindak penggelapan pajak. Menurut Undang-undang Nomor 6 Tahun 1983 tentang Ketentuan Umum dan Tata Cara Perpajakan, sistem pemungutan pajak di Indonesia memiliki corak dan ciri tersendiri dengan menganut self assessment system dimana masyarakat/wajib pajak diberikan kepercayaan penuh untuk menghitung, memperhitungkan, menyetor serta melaporkan kewajiban pajaknya, dan menunjukan sifat kegotongroyongan pajak sebagai wujud kewajiban kenegaraan setiap anggota masyarakat. Dengan berbagai akses kemudahan sistem perpajakan yang ada, baik dalam hal pelaporan SPT (Surat Pemberitahuan Tahunan) dan SSP (Surat Setoran Pajak), serta kemudahan dalam membayar pajaknya, diharapkan masyarakat/wajib pajak mampu bekerjasama dengan baik dan jujur dalam melaporkan kewajiban perpajakannya sehingga mampu menekan angka penggelapan pajak dan dapat meningkatkan penerimaan pajak untuk membiayai pembangunan nasional. Maka kesimpulannya semakin meningkat sistem perpajakan yang diterapkan maka perilaku penggelapan pajak akan menurun.

b. Hasil Uji Hipotesis 2 : Pengaruh pemahaman perpajakan terhadap persepsi Wajib Pajak (WPOP) atas perilaku penggelapan pajak

Berdasarkan pengujian hipotesis dengan menggunakan uji $t$, diketahui bahwa variabel pemahaman perpajakan mempunyai tingkat signifikasi sebesar 0,785 dan nilai $\mathrm{t}$ sebesar -0,274. Hal ini berarti Ho2 diterimasehingga dapat dikatakan bahwa pemahaman perpajakantidak berpengaruh terhadap perilaku penggelapan pajak karena tingkat signifikasi yang dimiliki variabel pemahaman perpajakan $>0,05(0,785>0,05)$ dan nilai t hitung $<2,01(0,274<2,01)$.

Hasil tersebut menunjukkan bahwa pemahaman yang dimiliki Wajib Pajak tidak mempengaruhi tindakan penggelapan pajak, dikarenakan dengan pemahaman yang semakin meningkat terkadang merubah sudut pandang/ persepsi Wajib Pajak mengenai perpajakan sehingga dapat mengurangi kepatuhan dalam mematuhi peraturan perpajakan atau penghindaran pajak ataupun sebaliknya.

c. Hasil Uji Hipotesis 3 : Pengaruh pelayanan aparat pajak terhadap persepsi Wajib Pajak orang pribadi(WPOP) atas perilaku penggelapan pajak.

Berdasarkan pengujian hipotesis dengan menggunakan uji $t$, diketahui bahwa variabel pelayanan aparat pajak mempunyai tingkat signifikasi sebesar 0,151 dan nilai t sebesar -1,463. Hal ini berarti Ho3 diterima sehingga dapat dikatakan bahwa pelayanan aparat pajak tidak berpengaruh secara signifikan terhadap perilaku penggelapan pajak karena tingkat signifikasi yang dimiliki variabel pelayanan aparat pajak $>0,05(0,151>0,05)$ dan nilai thitung $<2,01(-1,463<2,01)$. 
Hal ini dikarenakan Wajib Pajak membayar pajak berasal dari dorongan diri sendiri dan Wajib Pajak hanya mengingat pelayanan disaat melakukan kewajiban membayar pajak, dimana pelayanan yang kurang baik cenderung menghambat Wajib Pajak dalam mematuhi peraturan pajak dan terjadi penggelapan pajak.

d. Hasil Uji Hipotesis 4 : Pengaruh sanksi perpajakan terhadap persepsi wajib pajak orang pribadi(WPOP) atas perilaku penggelapan pajak

Berdasarkan pengujian hipotesis dengan menggunakan uji t, diketahui bahwa variabel sanksi perpajakan mempunyai tingkat signifikasi sebesar 0,026dan nilai t sebesar 2,307. Hal ini berarti Ho4 ditolak sehingga dapat dikatakan bahwa sanksi perpajakan berpengaruh negatif dan signifikan terhadap perilaku penggelapan pajak karena tingkat signifikasi yang dimiliki variabel sanksi perpajakan $\langle 0,05(0,026\rangle 0,05)$ dan nilai t hitung > 2,01 (-2,307> 2,01).Hasil penelitian ini konsisten dengan penelitian yang dilakukan dengan Rachmadi (2014) yang menyatakan bahwa sanksi perpajakan berpengaruh negatif terhadap tindakan penggelapan pajak.

Hal ini menyatakan tingkat sanksi perpajakan yang diterapkan itu sangat berkaitan dengan tindakan penggelapan pajak. Ketika masyarakat atau Wajib Pajak menganggap bahwa sanksi perpajakan ditingkatkan maka dia akan cenderung untuk patuh terhadap aturan perpajakan dalam hal ini berati tidak melakukan penghindaran Pajak (Tax Evasion), karena masyarakat/WP takut jika ketika diperiksa dan ternyata melakukan penggelapan pajak atau penghindaran pajak maka dana yang akan dikeluarkan untuk membayar denda akan jauh lebih besar dari pada pajak yang sebenarnya harus dia bayar. Setiap sanksi yang diberikan oleh pihak fiskus sifatnya transparan, proporsional dan diimplementasikan sesuai dengan ketetapan-ketetapan yang telah diputuskan sebelumnya. Sifat yang mengikat tersebut membuat sanksi pajak juga memegang peranan penting guna mendorong Wajib Pajak untuk patuh dalam memenuhi segala kewajiban perpajakannya dan membuat Wajib Pajak menghindari tindakan penggelapan pajak. Maka dengan semakin tinggi atau beratnya sanksi perpajakan, maka akan mengurangi tindakan penggelapan pajak, begitu juga sebaliknya jika semakin rendah tingkat sanksi perpajakan maka akan membuat pertambahan tindakan penggelapan pajak.

\section{Hasil Uji Signifikasi Simultan (Uji Statistik F)}

Uji $\mathrm{F}$ ini bertujuan untuk mengetahui ada tidaknya pengaruh bersama-sama variabel independen (bebas) terhadap variabel dependen (terikat). Pembuktian dilakukan dengan cara membandingkan nilai $\mathrm{F}$ hitung dengan $\mathrm{F}$ tabel pada tingkat kepercayaan 5\% dan derajat kebebasan (degree of freedom) $\mathrm{df}=(\mathrm{n}-\mathrm{k}-1)$ dimana $\mathrm{n}$ adalah jumlah responden dan k adalah jumlah variabel.

Kriteria pengujian yang dilakukan adalah:

a. Jika F hitung > F tabel maka Ho ditolak dan Ha diterima.

b. Jika F hitung < F tabel maka Ho diterima dan Ha ditolak. 
Selain itu uji $\mathrm{F}$ dapat juga diukur dengan melihat perbandingan besarnya probabilitas value ( $\mathrm{p}$ value) dengan taraf signifikasi 0,05 (taraf signifikan $\mathrm{a}=5 \%$ ). Adapun kriteria pengujiannya adalah :

a. Jika $\mathrm{P}$ value $>0,05$ maka Ho diterima dan Ha ditolak.

b. Jika $\mathrm{P}$ value $<0,05$ maka Ho ditolak dan Ha diterima.

Tabel 12

Hasil Uji Signifikasi Simultan (Uji Statistik F)

ANOVA $^{\mathrm{a}}$

\begin{tabular}{ll|r|r|r|r|r|}
\hline Model & Sum of Squares & Df & Mean Square & F & Sig. \\
\hline & Regression & 59,987 & 4 & 14,997 & 4,515 &, $004^{\mathrm{b}}$ \\
Residual & 139,502 & 42 & 3,321 & & \\
Total & 199,489 & 46 & & & \\
\hline
\end{tabular}
a. Dependent Variable: TY
b. Predictors: (Constant), TX4, TX3, TX1, TX2
Sumber : Olahan (2016)

Dari tabel ANOVA diatas diketahui nilai $\mathrm{F}$ menunjukkan bahwa dari hasil uji F diperoleh nilai $\mathrm{F}$ hitung sebesar 4,515 yang lebih besar dari Ftabel sebesar 2,594 (F tabel : [n-k-1] = 2,594). Kemudian jika dilihat dari nilai probabilitas yaitu sebesar0,004< 0,05 (tingkat sig 5\%). Dengan ini Ha diterima Karena tingkat signifikasi lebih kecil dari 0,05 maka dapat dikatakan bahwa sistem perpajakan, pemahaman perpajakan, pelayanan aparat pajak, dan sanksi perpajakan terhadap perilaku penggelapan pajak berpengaruh secara simultan (bersama-sama).

Dengan demikian dalam upaya mengurangi penggelapan pajak pemerintah perlu melakukan perbaikan sistem yang lebih baik lagi dan meningkatkan pemahaman perpajakan bagi Wajib Pajak dalam hal perpajakan dan meningkatkan pelayanan aparat pajak sesuai dengan prosedur, meningkatkan sanksi perpajakan sehingga tidak terjadi hilangnya pemasukan pajak Negara yang dapat digunakan sebagai pembangunan. Jika hal tersebut tidak ditindaklanjuti, maka akan menyebabkan akibat yang buruk seperti yang diungkapkan oleh Siahaan (2010) penggelapan pajak membawa akibat pada perekonomian secara makro. Penelitian ini konsisten dengan penelitian yang dilakukan oleh Suminarsasi (2011), Rachmadi (2014). 


\section{Hasil Uji Koefisien Determinasi}

Koefisen determinan digunakan untuk melihat seberapa besar pengaruh sistem perpajakan, pemahaman perpajakan, pelayanan aparat pajak, sanksi perpajakan terhadap perilaku penggelapan pajak. Adapun hasil uji determinan dengan menggunakan alat bantu SPSS dilihat pada tabel dibawah ini.

Tabel 13

Koefisien Determinan

Model Summaryb

\begin{tabular}{|l|r|r|r|r|}
\hline Model & R & R Square & $\begin{array}{c}\text { Adjusted R } \\
\text { Square }\end{array}$ & $\begin{array}{c}\text { Std. Error of the } \\
\text { Estimate }\end{array}$ \\
\hline 1 &, $548^{\mathrm{a}}$ &, 301 &, 234 & 1,822 \\
\hline
\end{tabular}

a. Predictors: (Constant), TX4, TX3, TX1, TX2

b. Dependent Variable: TY

Sumber : Olahan (2016)

Berdasarkan tabel diatas, hasil pengujian menunjukkan besarnya koefisien korelasi berganda $(\mathrm{R})$, koefisien determinasi ( $R$ Square), dan koefisien determinasi yang disesuaikan (Adjusted $R$ square). Berdasarkan tabel Model Summary diatas diperoleh bahwa nilai koefisien korelasi berganda $(\mathrm{R})$ sebesar $0,548^{a}$. ini menunjukkan bahwa variabel sistem perpajakan, pemahaman perpajakan, pelayanan aparat pajak, dan sanksi perpajakan terhadap perilaku penggelapan pajak mempunyai hubungan yang cukup. Hasil pada tabel diatas juga menunjukkan bahwa nilai koefisien determinasi ( $R$ Square) sebesar 0,301 dan nilai koefisien determinasi yang sudah disesuaikan (Adjusted $R$ square) adalah 0,234.

Hal ini berarti 30,1\% variasi dari perilaku penggelapan pajak bisa dijelaskan oleh variasi variabel independen ( Sistem Perpajakan, Pemahaman Perpajakan, Pelayanan Aparat Pajak, dan Sanksi Perpajakan terhadap Persepsi WPOP atas Perilaku Penggelapan Pajak). Sedangkan sisanya $(100 \%-30,1 \%=69,9 \%)$ dijelaskan oleh variabel lain yang tidak dimasukkan dalam model penelitian ini seperti variabel lain yang tidak dimasukkan dalam model penelitian ini seperti variabel kemungkinan terjadinya kecurangan (Ayu dan Hastuti 2009), keadilan (Wahyu, dan Supriyadi 2012) diharapakan variabel lain ini juga akan mempengaruhi penggelapan pajak. 
Jadi terdapat banyak variabel-variabel yang dapat mempengaruhi penggelapan pajak, dengan mengetahui faktor apa saja yang mempengaruhi penggelapan pajak, maka akan mencegah terjadinya penggelapan pajak yang sering terjadi di Indonesia, sehingga kasus perpajakan lainnya dapat terungkap.

\section{KESIMPULAN}

Berdasarkan hasil penelitian tentang faktor-faktor yang mempengaruhi persepsi Wajib Pajak Orang Pribadi atas perilaku penggelapan pajak dengan responden Wajib Pajak Orang Pribadi yang berprofesi dosen Prodi akuntansi di Universitas yang terakreditasi B dan berlokasi di Palembang. Adapun variabel-variabel penelitian yang digunakan adalah sistem perpajakan, pemahaman perpajakan, pelayanan fiskus, dan sanksi perpajakan. Dan berdasarkan hasil analisis dan pembahasan penelitian ini dapat ditarik kesimpulan sebagai berikut :

1. Sistem perpajakan berpengaruh terhadap persepsi Wajib Pajak Orang Pribadi atas perilaku penggelapan pajak. hal ini menunjukkan bahwa semakin baik sistem perpajakan yang diterapkan maka tingkat kepatuhan semakin tinggi dimana kecenderungan melakukan penggelapan pajak akan menurun.

2. Pemahaman perpajakan tidak berpengaruh terhadap persepsi wajib pajak orang pribadi atas perilaku penggelapan pajak.dikarenakan persepsi responden yang berprofesi dosen mempunyai tingkat pendidikan dan integritas yang tinggi sehingga telah memahami jadi tidak akan melakukan penggelapan pajak dan menunjukkan juga bahwa pemahaman yang semakin meningkat terkadang merubah sudut pandang/ persepsi Wajib Pajak mengenai perpajakan sehingga dapat mengurangi kepatuhan dalam mematuhi peraturan perpajakan atau penghindaran pajak ataupun sebaliknya.

3. Pelayanan aparat pajak tidak berpengaruh terhadap persepsi Wajib Pajak Orang Pribadi atas perilaku penggelapan pajak. Wajib Pajak membayar pajak berasal dari dorongan diri sendiri dan Wajib Pajak hanya mengingat pelayanan disaat melakukan kewajiban membayar pajak, dimana pelayanan yang kurang baik cenderung menghambat Wajib Pajak dalam mematuhi peraturan pajak dan terjadi penggelapan pajak.

4. Sanksi perpajakan berpengaruh dan signifikan terhadap persepsi wajib pajak orang pribadi atas perilaku penggelapan pajak. Hal ini menunjukkan bahwa semakin tinggi dan beratnya sanksi perpajakan maka penggelapan pajak akan menurun.

5. Pengaruh sistem perpajakan, pemahaman perpajakan, pelayanan aparat pajak, dan sanksi perpajakan terhadap persepsi wajib pajak orang pribadi atas perilaku penggelapan pajak. hal ini menunjukkan secara bersama-sama seluruh variabel independen berpengaruh terhadap variabel dependen. 


\section{KETERBATASAN PENELITIAN}

Penelitian ini memiliki keterbatasan yang mempengaruhi hasil dari penelitian.

Beberapa keterbatasan dalam penelitian ini diantaranya :

1. Studi kasus hanya dilakukan pada tiga Perguruan Tinggi Swasta di Palembang sehingga memperoleh jumlah populasi yang tidak besar.

2. Penelitian ini memiliki keterbatasan dalam jumlah sampel penelitian yaitu hanya sebanyak 47 responden.

\section{SARAN}

Berdasarkan kesimpulan yang telah dibuat, maka penulis mengajukan saran sebagai acuan.

Penelitian selanjutnya disarankan :

a. Untuk peneliti selanjutnya diharapkan studi kasus tidak hanya pada perguruan tinggi swasta saja. Sehingga bisa mendapatkan jumlah populasi yang lebih besar.

b. Penelitian selanjutnya diharapkan dapat memperluas jumlah sampel penelitian serta variasi respnden penelitian bukan hanya wajib pajak sebagai dosen saja namun juga wajib pajak lainnya seperti pengusaha dan wajib pajak badan

c. Menambah variabel independen lainnnya seperti dskriminasi, keadilan yang merupakan faktor-faktor yang dapat mempengaruhi tingkat penggelapan pajak.

\section{DAFTAR PUSTAKA}

Agus N. Jatmiko. 2006. Pengaruh Sikap Wajib Pajak Pada Pelaksanaan Sanksi Denda, Pelayanan Fiskus, dan Kesadaran Perpajakan Terhadap Kepatuhan Wajib Pajak. Diponegoro.

Bimo Walgito. 2004. Pengantar Psikologi Umum. Yogyakarta: Andi.

Diana Sari. 2013. Konsep Dasar Perpajakan. Bandung: PT. Refika Aditama.

Ghozali, Imam. 2011. Aplikasi Analisis Multivariate Dengan Program SPSS. Semarang: Badan Penerbit Universitas Diponegoro.

Gibson, James,L. 2001. Organisasi, Perilaku, Struktur dan Proses. (Edisi ke-5). Jakarta: Erlangga.

Jogiyanto. 2007. Sistem Informasi Keperilakuan. Edisi Revisi. Yogyakata: Andi.

Kamus Besar Bahasa Indonesia. 2002. Departemen Pendidikan Nasional.(Edisi ke-3). Balai Pustaka, Jakarta: Gramedia. 
Mardiasmo. 2009. Perpajakan Edisi Revisi 2009. Yogyakarta: Andi.

Miftah, Toha. 2003. Perilaku Organisasi Konsep Dasar dan Aplikasinya. Jakarta: PT. Raja Grafindo Persada.

Prasetyo, S. 2010. Persepsi Etis Penggelapan Pajak Bagi Wajib pajak di wilayah Surakarta. Surakarta.

Rachmadi, W. 2014. Faktor-Faktor yang Mempengaruhi Persepsi Wajib Pajak Orang Pribadi atas Perilaku Penggelapan Pajak. Diponegoro.

Rahayu, Siti Kurnia. 2010. Perpajakan Indonesia: Konsep dan Aspek Formal. Yogyakarta: Graha Ilmu.

Republik Indonesia, Undang-Undang Nomor 28 Tahun 2007 tentang Perubahan Ketiga Atas Undang-Undang Nomor 6 Tahun 1983 Tentang Ketentuan Umum dan Tata Cara Perpajakan.

Resmi, Siti. 2009. Perpajakan Teori dan Kasus. Jakarta, Salemba Empat.

Safri Nurmantu. 2006. Pengantar Perpajakan. Jakarta: Granit.

Siahaan, Marihot P. 2010. Hukum Pajak Elementer. Yogyakarta: Graha Ilmu.

Soemitro, Rochmat, 2009. Dasar-Dasar Hukum Pajak dan Pajak Pendapatan. Bandung: Eresco.

Sugihartono, dkk. 2007.Psikologi Pendidikan. Yogyakarta: UNY Press.

Suminarsasi, Wahyu dan Supriyadi. 2011. Pengaruh Keadilan, Sistem Perpajakan dan Diskriminasi Terhadap Persepsi Wajib Pajak Mengenai Penggelapan Pajak. Yogyakarta, PPJK 15 Universitas Gajah Mada.

Sugiyono. 2009.Metode Penelitian Bisnis. Bandung: Alfabeta.

Sugiyono. 2012. Memahami Penelitian Kualitatif. Bandung: Alfabeta.

Priyatno, D. 2010. 5 Jam Belajar Olah Data dengan SPSS. Yogyakarta: Andi.

Prof.Dr.P.J.A. Andriani, 2010. Ekonomi Pembangunan. Edisi III dan IV. Universitas Gajah Mada, Yogyakarta. 
Prof.Dr.Rochmat Soemitro,S.H. 2007. Dasar-Dasar Hukum Pajak dan Pajak. Bandung: PT. Eresco.

Veronica, Carolina. 2009. Pengetahuan Pajak. Diakses pada April 2016 dari www.google.com

Waluyo. 2011.Perpajakan Indonesia. (Edisi Kesepuluh). Jakarta: Salemba Empat.

Wicaksono, 2014. Pengaruh Persepsi Sistem Perpajakan, Keadilan Pajak, Diskriminasi Pajak dan Pemahaman Perpajakan terhadap Perilaku Penggelapan Pajak. Diponegoro 